supply and sanitation decade is to provide good drinking water for all by 1989 .

Yet in Britain we take safe drinking water and an adequate sewerage system for granted, although Britain has no defined standards for drinking water. Water authorities are responsible among other things for water supply and conservation, sewage disposal (which is often carried out by district authorities on an agency basis), control of river pollution, land drainage, and the use of water for recreation. The Water Authorities Association enables authorities to work together and to talk with one voice to the government and other relevant organisations.

People in developed countries use about 180 to 440 litres of water each a day, and in Britain lakes, streams, and underground aquifiers are the main sources of water. The amount of treatment needed by the water depends on the quality of the source. Chlorination is used to ensure bacteriological safety, but filtration is needed to remove other pathogens; a failure in this system caused an outbreak of giardiasis in Bristol. ${ }^{3}$ Water supplies cannot be examined for all possible organisms that might cause disease, and so they are tested simply for concentrations of the normal gut flora of man and animals - that is, faecal coliform bacteria. The lack of defined standards for water supplies and the difficulties of testing for all potentially pathogenic organisms will make for difficulties in monitoring the quality of privatised supplies.

The British water and sewerage systems do have problems. The sewers are aging fast, particularly because of the weight of traffic, and many of the Victorian sewers simply empty sewerage into the sea. Large capital expenditure is needed to renew sewers and either to extend outfalls further from the shore or to build adequate treatment plants. ${ }^{4}$ In 1986 at least a fifth of sewerage treatment works in Britain failed to comply with the Control of Pollution Act 1974. Almost two thirds of waste water comes from industry and is more costly to treat than the water coming from private dwellings. Responding to these problems may be very expensive, and shareholders in a private company may be unwilling to pay or may want corners to be cut. They might also be reluctant to comply with strict new European Community directives on the quality of water because of the expense. ${ }^{5}$

Another potential difficulty is that most water authorities own the land surrounding the water catchment areas-so that they control what happens on that land. Private companies might be tempted to sell the land or rent it to the highest bidder and so lose control over its management. Other worries raised about privatisation centre on the lack of accountability of non-elected members of water authorities and on restrictions on the media being able to attend authority meetings.

All of these factors must be considered when a bill is drafted to privatise water supplies. But the record on privatisation makes me worry that they will not all be considered.

JAMES M DUNLOP

District Medical Officer

Hull Health Authority,

Hull HU2 8TD

1 Snow J. On the mode of communication of cholera. London: John Churchill, 1855

2 Department of the Environment, Ministry of Agriculture, Fisheries, and Food. Privatisation of the water authorities in England and Wales. White Paper. London: HMSO, 1986. (Cmnd 9734.)

3 Jephcott AE, Begg NT, Baker IA. Outbreak of giardiasis associated with mains water in the United Kingdom. Lancet 1986; : 730-2.

4 National Economic Development Office. Investment in the public built infrastructure. London: NEDO Books, 1985.

5 World Health Organisation. Guidelines for drinking water quality. Vol I. Recommendations. Geneva: WHO, 1984.

\section{Lichen sclerosus et atrophicus}

Lichen sclerosus et atrophicus is a skin condition that affects both sexes, of all ages, and all areas of the body. Although it is not common, general practitioners will see it from time to time; and urologists, paediatricians, gynaecologists, specialists in genitourinary medicine, and pathologists as well as dermatologists may have to help in its management.

Lichen sclerosus et atrophicus has a typical clinical appearance (see figures), with ivory papules that coalesce into crinkly atrophic plaques, commonly showing speckled purpura. Histological examination shows that the epidermis
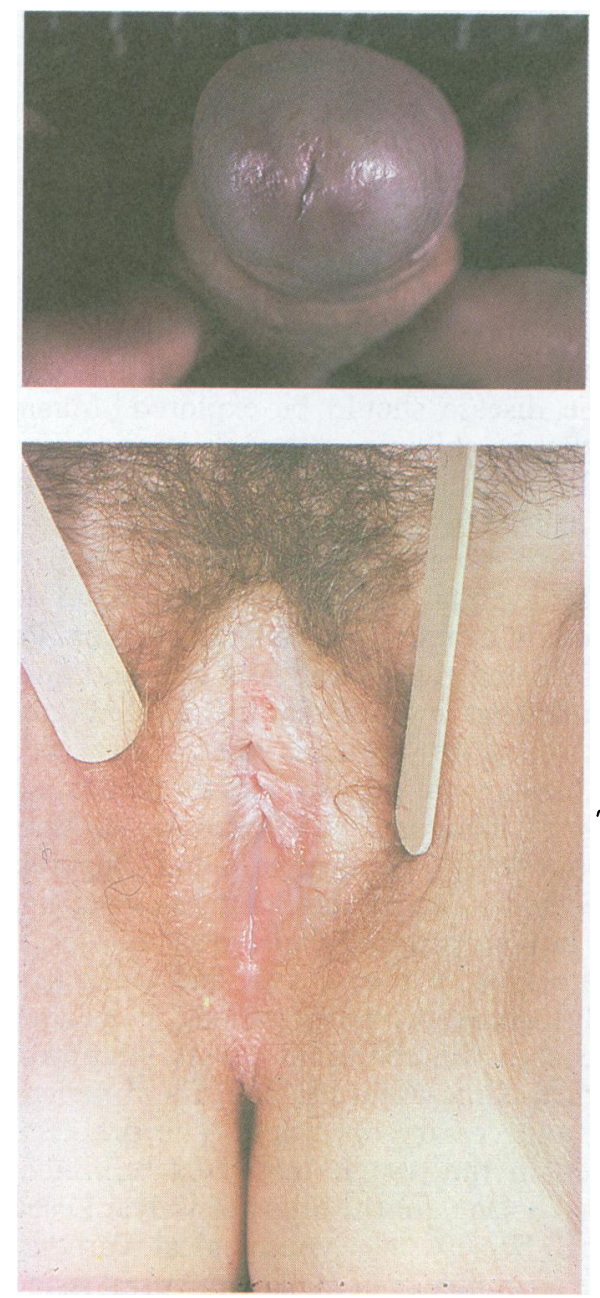

is thinned and that there is a subepidermal zone of featureless hyalinisation in which vessels are unsupported (hence extravasated red cells are often seen) above a deeper band of inflammatory cells. If the condition is severe and inflamed the epidermis may be hyperkeratotic and acanthotic. The aetiology of lichen sclerosus et atrophicus is obscure, but a link with autoimmune disease has been shown. ${ }^{1-4}$ Many examples of familial incidence have been reported, and lichen sclerosus et atrophicus has been reported in identical twins, ${ }^{5}$ but HLA studies have been inconclusive.

In boys lichen sclerosus et atrophicus may cause phimosis. Material from circumcisions done for medical reasons is usually discarded, but in one study lichen sclerosus et atrophicus was shown to be the cause of phimosis in 14 of 100 boys aged 1 to 15 years; 13 of the cases were in the 59 boys 
aged 5 to $11 .{ }^{6} \mathrm{Lichen}$ sclerosus et atrophicus also affects adult men on the penis (usually the glans, prepuce, or both') or elsewhere, and in older men it is the commonest cause of balanitis xerotica obliterans, a possibly premalignant condition. The clinical course of lichen sclerosus et atrophicus in relation to the three age groups is obscure. In adults circumcision is usually beneficial for lichen sclerosus et atrophicus of the glans and of the prepuce, and a strong corticosteroid is also helpful.

In young girls lichen sclerosus et atrophicus probably affects the anogenital area most commonly but certainly not exclusively. The strikingly pale, atrophic, and speckled lesions may be symptomless, but they may itch, perhaps become infected with staphylococci or streptococci, and even lead to intractable constipation because of discomfort on defecation. The condition, especially if coupled with the purpura, haemorrhagic blisters, and frank bleeding induced by scratching or washing, may lead to false suspicions of sexual abuse. ${ }^{89}$ Lichen sclerosus et atrophicus is managed in these patients with bland emollients, good hygiene, and sometimes a mild corticosteroid. Lesions improve at puberty but probably do not remit completely.

Lichen sclerosus et atrophicus may present at any age in adult women and commonly affects the anogenital area, causing itching or soreness. The possibility of associated autoimmune disease should be explored. Management is similar to that in children, although strong corticosteroids are justifiable for short periods. Testosterone ointment is thought beneficial by some but is not widely used in Britain. The condition never affects the vagina, but dyspareunia may be caused by introital stenosis. Pregnancy and delivery are uninfluenced by lichen sclerosus et atrophicus. Patients can be helped by being given a leaflet on the condition; and they should be told that an operation is indicated only to obtain biopsy specimens, for rare cases where adhesions may form, sometimes for introital stenosis, and for malignancy.

The risk of malignancy (squamous cell carcinoma) is raised, about $6 \%,{ }^{210}$ and continuing supervision thus seems indicated. The factors that cause malignancy are unknown, but human papillomavirus may be important. The dermatologist, gynaecologist, and pathologist need to work closely together to manage patients with lichen sclerosus et atrophicus: if the condition passes unappreciated in a gynaecological clinic unjustifiable fears of malignancy may lead to an unnecessary operation. The problem has been compounded in the past by confused terminology. ${ }^{11}$ The International Society for the Study of Vulvar Disease and the International Society of Gynecological Pathologists have clarified the terminology of malignant vulval lesions, ${ }^{12}$ and at its congress in 1987 the former ratified a new and more satisfactory terminology for non-malignant epithelial conditions, which is likely to be adopted also by the gynaecological pathologists. When lichen sclerosus et atrophicus is clearly described in histological terms, with the presence or absence of changes in response to rubbing, human papillomavirus infection, and malignancy noted, we shall have a sound base from which to explore other facets of this disease.

C M RIDLEY

Consultant Dermatologist,

Elizabeth Garrett Anderson and Whittington Hospitals,

London NW1 2AP

1 Harrington CI, Dunsmore IR. An investigation into the incidence of autoimmune disorders in patients with lichen sclerosus et atrophicus. Br J Dermatol 1981;104:563-6.

2 Meyrick Thomas RH, Ridley CM, McGibbon DH, Black MM. Lichen sclerosus et atrophicus and autoimmunity in 350 women. Brf Dermatol (in press).
3 Meyrick Thomas RH, Ridley CM, Black MM. The association of lichen sclerosus et atrophicus to autoimmune related disease in males. Brf Dermatol 1983;109:661-4.

4 Meyrick Thomas RH, Ridley CM, Black MM. The association of lichen sclerosus et atrophicus and autoimmune related diseases in males: an addendum. Brf Dermatol 1984;111:371.

5 Meyrick Thomas RH, Kennedy CTC. The development of lichen sclerosus et atrophicus in monozygotic twin girls. Br $\mathcal{J}$ Dermatol 1986;114:377-9.

6 Chalmers RTG, Burton PA, Bennett RF, Goring CC, Smith PJB. Lichen sclerosus et atrophicus: Chalmers RTG, Burton PA, Bennett RF, Goring CC, Smith PJB. Lichen sclerosus et atrop
a common and distinctive cause of phimosis in boys. Arch Dermatol 1984;120:1025-7.

7 Meyrick Thomas RH, Ridley CM, Black MM. Clinical features and therapy of lichen sclerosus et atrophicus affecting males. Clin Exp Dermatol 1987;12:126-8.

8 Handfield-Jones SE, Hinde FRJ, Kennedy CTC. Lichen sclerosus in children misdiagnosed as sexual abuse. Br Med F 1987;294:1404-5.

9 Priestley BL, Bleehen SS. Lichen sclerosus et atrophicus in children misdiagnosed as sexual abuse. BrMed f 1987;295;211.

10 Wallace HJ. Lichen sclerosus et atrophicus. Transactions of the St John's Hospital Dermatological Society 1971;57:9-30.

11 Ridley CM. Recent advances in vulval diseases. In: Champion RH, ed. Recent advances in dermatology. London: Churchill Livingstone, 1986:127.

12 Ridley CM. Nomenclature of non-neoplastic vulval conditions. Br f Dermatol 1986;115:647-8.

\section{Saving skin}

How many diagnoses do doctors miss simply by not thinking of them? Occupational dermatitis is the commonest occupational disease, with half of all the diseases prescribed for industrial injury benefit in 1982-3 being "non-infective dermatitis of external origin."' Yet it is only too easy to see patients with dermatitis of the hands more in terms of $\subseteq$ medicaments than of investigation, diagnosis, and preven- $N$ tion. The Health and Safety Executive has just launched a $z$ year's campaign to heighten awareness of occupational dermatitis. Its Employment Medical Advisory Service is 3 taking the campaign directly to both the workforce and management as well as publicising it to doctors, nurses, occupational hygienists, and other specialists.

Occupational dermatitis may usefully be defined as dermatitis that would not have occurred had the patient not been carrying out his or her work. It is a contact dermatitis, the result of the skin's reaction to irritants or allergens-irritants that attack directly (such as alkalis) and allergens that attack through a delayed cell mediated allergic mechanism (such as chromate). Not all occupational skin disease is contact dermatitis - the term includes skin diseases as diverse as urticaria and carcinoma-but the great majority is.

The true prevalence of occupational dermatitis is not known for any part of the world. Many cases escape being included in any statistical report because the patient goes on working and does not claim any compensation. Most figures quoted are therefore underestimates. Some inkling of how large the true figure might be, however, is provided by the results of a population study in the United States. ${ }^{2}$ Nearly a third of a 20000 sample of the general population were found $\stackrel{N}{\sim}$ to have "some skin pathology that should be evaluated by a $\frac{7}{0}$ physician" and of this group nearly a quarter had occupational exposure to agents that were potentially toxic to the N skin. Prevalence figures are always difficult to assess, if only

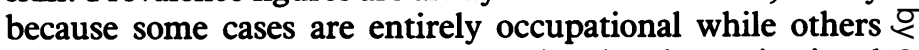
result from a combination of occupational and constitutional $\stackrel{\odot}{\subset}$ factors, such as shampooing and atopic eczema. Nevertheless, the impact of occupational dermatoses on the personal, social, and economic life of patients tends to be underestimated by others, sometimes even by doctors. The effect $\stackrel{\otimes}{\stackrel{\nabla}{D}}$ of chronic chromate dermatitis, for example, may be com- $\stackrel{\mathbb{\Phi}}{\AA}$ parable with that of the amputation of a limb, a comparison aptly crystallised in the phrase "chromate cripple."

Scarcely any substance is entirely harmless to the skin if $\frac{8}{2}$ direct contact is heavy or prolonged enough, and even office 